\title{
PERBANDINGAN ANALISA LAPORAN KEUANGAN PERUSAHAAN JASA DAN PABRIKASI UNTUK MENILAI KINERJA PERUSAHAAN
}

\author{
Kirana Ikhtiari \\ Dosen Fakultas Ekonomi Universitas Muslim Indonesia Makassar \\ Eka Ariaty Arfah \\ Dosen Fakultas EkonomiSTIE Wira Bhakti Makassar \\ e-mai:ekha_sweet82@yahoo.co.id
}

\begin{abstract}
ABSTRAK
Tujuan utama perusahaan adalah untuk memaksimalkan kemakmuran stakeholder, hal ini dapat dicapai dengan memaksimalkan nilai perusahaan dengan pencapaian profit setiap tahunnya. Salah satu cara untuk menilai kinerja perusahaan adalah dengan menganalisa laporan keuangan. Tujuan dari penelitian ini adalah untuk mengetahui kinerja keuangan PT. Indosat Tbk dan PT HM. Sampoerna Tbk dengan menggunakan Analisis Rasio Keuangan (Rasio Likuiditas, Rasio Solvabilitas, Rasio Aktifitas, dan Rasio Rentabilitas) dan untuk mengetahui perbandingan kinerja keuangan yang terjadi di PT. Indosat Tbk dan PT HM. Sampoerna Tbk.

Pendekatan penelitian yang digunakan penulis dalam penelitian ini adalah penelitian deskriptif kuantitatif. Metode pengumpulan data dalam penelitian ini adalah dengan menggunakan metode Studi Dokumentasi. Dari berbagai dokumen dan data yang telah diolah yang diperoleh langsung dari Perusahaan Manufaktur yang terdaftar di Bursa Efek Indonesia berupa Laporan Keuangan .

Hasil penelitian pada PT Indosat, Tbk dan PT. HM. Sampoerna yaitu pencapaian Rasio Likuiditas PT Indosat, Tbk dari tahun 2016 mengalami penurunan dibandingkan standar Rasio Likuiditas Rata-rata Industri Sejenis. Pencapaian Rasio Solvabilitas PT. HM. Sampoerna, Tbk dari tahun 2016 menunjukkan hasil yang baik. Berdasarkan Rasio Aktivitas ada indikasi bahwa kinerja keuangan PT Indosat, Tbk masih belum baik dilihat dari pencapaian Rasio Aktivitas karena masih di bawah standar Rasio Rata-rata Industri Sejenis. Sedangkan Rasio Profitabilitas PT. HM. Sampoerna, Tbk. menunjukkan hasil kinerja yang baik dimana pencapaian hasil kinerja tersebut khususnya indikasi dari Net Profit Margin berada diatas dari standar pencapaian Rasio rata-rata Industri Sejenis.
\end{abstract}

Kata Kunci : Kinerja Keuangan, Laba, Aktiva, Perusahaan

\section{PENDAHULUAN}

Dalam era perdagangan bebas ini, perubahan dan mobilitas keuangan internasional semakin cepat maka akan mempengaruhi semua aspek kehidupan termasuk Akuntansi dan Keuangan. Dengan semakin majunya perkembangan dunia usaha, persaingan antar perusahaan pun semakin meningkat. Agar dapat 
tetap bertahan dalam dunia bisnis setiap perusahaan harus berhati-hati dalam mengambil keputusan terutama keputusan di bidang keuangan. Hal ini disebabkan karena kegagalan atau keberhasilan usaha hampir sebagian besar ditentukan oleh kualitas keputusan yang berkaitan dengan keuangan.

Pada umumnya perusahaan didirikan untuk memperoleh laba dengan tujuan untuk menjaga eksistensi perusahaan tersebut. Namun tujuan perusahaan yang seharusnya dipergunakan sebagai patokan untuk menilai benar atau tidaknya keputusan yang diambil dalam bidang keuangan adalah meningkatnya atau memaksimumkan nilai perusahaan.

Nilai perusahaan merupakan harga yang bersedia dibayar oleh para atau calon investor atau pembeli apabila bermaksud untuk menjalankan usaha tersebut. Bagi perusahaan yang sudah go public, yaitu yang sudah menerbitkan dan menjual sahamnya di pasar modal, nilai perusahaan akan tercermin dari harga saham perusahaan. Apabila perusahaan mengambil suatu kebijakan keuangan, maka kebijakan yang diputuskan harus membuat reaksi yang positif bagi investor sehingga dapat berpengaruh terhadap kenaikan harga saham perusahaan. Sebaliknya apabila kebijakan yang diambil buruk, maka akan membuat reaksi yang negatif bagi investor sehingga dapat mempengaruhi penurunan harga saham perusahaan. Jadi, keputusan keuangan yang baik merupakan keputusan yang dapat meningkatkan kesejahteraan para pemegang saham perusahaan yaitu dengan meningkatkan nilai perusahaan.

Maka dari itu, dalam usaha mencapai tujuan perusahaan sangat diperlukan kemampuan dan keahlian manajemen dalam meningkatkan efektivitas dan efisiensi organisasi secara keseluruhan sehingga dapat tetap eksis ditengah persaingan bisnis yang kian pesat dan ketat.Efektivitas suatu perusahaan dapat terlihat dengan jelas pada kinerja perusahaanya.Apalagi dimasa sekarang ini persaiangan di dunia usaha semakin ketat, berbagai perusahan saling berkompetisi untuk memperebutkan pasarnya.Oleh karena itu perusahaan sebagai badan usaha harus berkompetisi dengan perusahaan-perusahaan lain untuk menggaet pangsa pasar yang ada.

Untuk bisa mengalahkan kompetitor dalam merebut pangsa pasar yang ada, maka sebuah perusahaan haruslah membuat analisis tentang kinerjanya sendiri serta kinerja kompetitor lainnya lain. Hasil analisis ini dapat digunakan oleh perusahaan untuk megevaluasi kinerja perusahaan dan juga digunakan sebagai bahan pembuatan keputusan manajemen perusahaan tersebut.

Suatu perusahaan dikatakan berhasil memenangkan kompetisi bisnisnya jika perusahaan itu mampu memenuhi permintaan dan kebutuhan masyarakat dengan mengembangkan jasa-jasa atau produk yang lebih baik, menarik dan menyenangkan daripada kompetitornya, sekaligus mampu mengadaptasi diri dengan setiap perubahan lingkungan. bank harus bisa mengubah ancaman lingkungan menjadi peluang yang menguntungkan.

Pengukuran kinerja meliputi beberapa bidang antara lain: bidang produksi, pemasaran dan keuangan. Pada bidang produksi manajemen harus mampu menghasilkan suatu produk yang mutunya lebih baik dengan harga yang lebih murah dan perputaran produksinya tepat waktu. Hal ini berarti bahwa apabila manajemen ingin memenangkan persaingan maka harus mampu mencapai suatu 
tingkat kualitas yang lebih dari produk lainnya yang sejenis. Tetapi permasalahannya bukan hanya terletak pada mutu produk, tetapi dari segala aspek yaitu meliputi mutu bahan baku, kualitas tenaga kerja dan kualitas produk yang bermutu tinggi guna menjaring pasar yang lebih luas dan kuat. Dengan kata lain, suatu perusahaan dapat bertahan dan berkembang, apabila memiliki keunggulan kualitas produk, sehingga fungsi pemasaran dengan mudah dapat dikembangkan.

Bidang lain yang merupakan faktor penting yang mempengaruhi kinerja perusahaan adalah di bidang keuangan. Bidang ini merupakan salah satu bidang utama yang memiliki pengaruh besar dalam jalannya sebuah perusahaan. Hal ini dikarenakan keberhasilan perusahaan masih dilihat dari faktor keuntungan yang diperoleh. Manajemen keuangan adalah untuk memaksimalkan nilai perusahaan. Memaksimalkan nilai perusahaan bermakna lebih luas dari pada memaksimalkan nilai laba, karena memaksimalkan nilai selain bertujuan untuk meningkatkan laba juga mencakup efisiensi atas penggunaan modal dan sumber daya lainnya. Semakin berhasil suatu perusahaan memaksimalkan nilainya, maka mutu dan jumlah keuntungan yang dihasilkan juga semakin membaik. Hal ini sangat berkaitan erat dengan pemenuhan harapan bagi para pemegang saham, yaitu berupa peningkatan nilai saham dan deviden atas saham yang dimilikinya.

Untuk dapat mengambil keputusan yang tepat diperlukan suatu informasi mengenai keuangan perusahaan yang tersedia tepat waktu, dapat ditelusuri kebenarannya, jelas, lengkap, dan akurat. Dalam hal ini perusahaan akan menyusun suatu laporan keuangan yang sangat perlu untuk mengetahui kondisi keuangan perusahaan. Pada mulanya laporan keuangan bagi suatu perusahaan hanyalah sebagai 'alat penguji' dari pekerjaan bagian pembukuan, tetapi untuk selanjutnya laporan keuangan tidak hanya sebagai alat penguji saja tetapi juga sebagai dasar untuk dapat menentukan atau menilai posisi keuangan perusahaan tersebut, dimana dengan hasil analisa tersebut pihak-pihak yang berkepentingan mengambil suatu keputusan. Jadi untuk mengetahui posisi keuangan suatu perusahaan serta hasil-hasil yang telah dicapai oleh perusahaan tersebut perlu adanya laporan keuangan dari perusahaan yang bersangkutan.

Laporan keuangan pada dasarnya adalah hasil dari proses akuntansi yang dapat digunakan sebagai alat komunikasi antara data keuangan atau aktivitas suatu perusahaan dengan pihak-pihak yang berkepentingan dengan data atau aktivitas perusahaan tersebut. Dalam menganalisis dan menginterpretasikan laporan keuangan yang bersangkutan, maka digunakan metode-metode tertentu yang telah baku. Pada umumnya dalam menganalisis laporan keuangan digunakan analisis rasio yang terdiri atas rasio likuiditas, solvabilitas, profitabilitas, dan aktivitas.

Hasil analisis tersebut sangat penting artinya bagi pimpinan perusahaan untuk mengontrol kebijakan-kebijakan yang telah diambil baik kondisi keuangan yang lalu, saat ini maupun yang akan datang dalam rangka menjalankan operasi perusahaan dan membantu dalam mengambil berbagai keputusan yang harus dilaksanakan secepat mungkin agar tujuan perusahaan itu dapat tercapai.

Berdasarkan latar belakang di atas maka penulis merumuskan beberapa masalah sebagai berikut: Bagaimana mengukur kinerja keuangan perusahaan 
dengan menggunakan Analisis Rasio Keuangan (Rasio Likuiditas, Rasio Solvabilitas, Rasio Aktifitas, dan Rasio Rentabilitas) ; Bagaimana perbandingan kinerja keuangan yang terjadi dalam perusahaan.

Adapun tujuan dari penelitian ini adalah sebagai berikut:Untuk mengetahui kinerja keuangan perusahaan dengan menggunakan Analisis Rasio Keuangan (Rasio Likuiditas, Rasio Solvabilitas, Rasio Aktifitas, dan Rasio Rentabilitas) dan untuk mengetahui perbandingan kinerja keuangan yang terjadi di perusahaan.

\section{Laporan Keuangan}

Laporan keuangan merupakan media yang dipakai untuk meneliti kondisi kesehatan perusahaan yang terdiri dari neraca, perhitungan rugi laba, ikhtisar laba yang ditahan, dan laporan posisi keuangan. (Agnes, 2005).

Menurut Harahap (1999) laporan keuangan adalah: "menggambarkan kondisi keuangan dan hasil usaha suatu perusahaan pada saat tertentu atau jangka waktu tertentu". Bambang (1999) mendefinisikan laporan keuangan sebagai berikut : "Laporan Financial (Financial Statement), memberikan ikhtisar mengenai keadaan finansial suatu perusahaan, dimana Neraca (Balance Sheet) mencerminkan nilai aktiva, utang dan modal sendiri pada suatu saat tertentu, dan Laporan Rugi Laba (Income Statement) mencerminkan hasilhasil yang dicapai selama suatu periode tertentu biasanya meliputi periode satu tahun ".

Dari pendapat-pendapat tersebut diatas dapat diambil kesimpulan bahwa pengertian laporan keuangan adalah suatu daftar yang menggambarkan posisi keuangan suatu perusahaan pada suatu saat tertentu dan hasil usahanya selama periode tertentu.

Laporan Keuangan pada dasarnya merupakan hasil proses akuntansi yang dapat digunakan sebagai alat untuk berkomunikasi antara data keuangan ataupun aktivitas suatu perusahaan dengan berbagai pihak yang berkepentingan akan data dimaksud. Adapun pihak-pihak yang berkepentingan terhadap keadaan keuangan suatu perusahaan menurut Sofyan (2001) antara lain :

\section{a. Pemegang Saham}

Bagi pemegang saham (pemilik perusahaan) laporan keuangan digunakan untuk

1. Menilai prestasi atau hasil yang dicapai oleh manajemen.

2. Mengetahui hasil deviden yang akan diterima.

3. Menilai posisi keuangan perusahaan dan pertumbuhannya.

4. Mengetahui nilai saham dan laba per lembar saham.

5. Sebagai dasar untuk memprediksi kondisi perusahaan di masa yang akan datang.

6. Sebagai dasar untuk mempertimbangkan menambah atau mengurangi investasi.

\section{b. Manajemen Perusahaan}

Bagi manajemen perusahaan laporan keuangan digunakan untuk :

1. Pertanggungjawaban pengelolaan kepada pemilik.

2. Mengukur tingkat biaya dari setiap kegiatan operasi perusahaan, divisi, bagian, atau segmen. 
3. Mengukur tingkat efisiensi dan tingkat keuntungan perusahaan, divisi, bagian, atau segmen.

4. Menilai hasil kerja individu yang diberi tugas dan tanggung jawab.

5. Untuk menjadi bahan pertimbangan dalam menentukan perlu tidaknya diambil kebijaksanaan baru.

c. Investor

Bagi investor laporan keuangan digunakan untuk :

1. Menilai kondisi keuangan dan hasil usaha perusahaan.

2. Menilai kemungkinan menanamkan dana dalam perusahaan.

3. Menilai kemungkinan divestasi (menarik investasi) dari perusahaan.

d. Kreditur

Bagi kreditur laporan keuangan digunakan untuk :

1. Menilai kondisi keuangan dan hasil usaha perusahaan baik dalam jangka pendek maupun dalam jangka panjang.

2. Menilai kualitas jaminan kredit/ investasi untuk menopang kredit yang akan diberikan.

3. Melihat dan memprediksi prospek keuntungan yang mungkin diperoleh dari perusahaan.

4. Menilai likuiditas, solvabilitas, dan rentabilitas perusahaan sebagai dasar dalam pertimbangan keputusan kredit.

5. Menilai sejauh mana perusahaan mengikuti perjanjian kredit yang sudah disepakati.

\section{e. Pemerintah}

Bagi pemerintah laporan keuangan digunakan untuk :

1. Menghitung dan menetapkan jumlah pajak yang harus dibayar.

2. Sebagai dasar dalam penetapan-penetapan kebijaksanaan baru

3. Menilai apakah perusahaan memerlukan bantuan atau tindakan lain

4. Menilai kepatuhan perusahaan terhadap aturan yang telah ditetapkan

5. Bagi lembaga pemerintahan lainnya bisa menjadi bahan penyusunan data dan statistik.

\section{Tujuan Laporan Keuangan}

Tujuan laporan keuangan menurut Ikatan Akuntansi Indonesia (2004) adalah sebagai berikut:

a. Menyediakan informasi yang menyangkut posisi keuangan, kinerja serta perubahan posisi keuangan suatu perusahaan yang bermanfaat bagi sejumlah besar pemakai dalam pengambilan keputusan ekonomi.

b. Laporan yang disusun untuk tujuan memenuhi kebutuhan bersama sebagian besar pemakai.

c. Laporan keuangan juga menunjukkan apa yang dilakukan manajemen (stewardship), atau pertanggungjawaban manajemen atas sumber daya yang dipercayakan kepadanya.

\section{Bentuk Laporan Keuangan}


Untuk menganalisis dan menafsirkan suatu laporan keuangan menurut Suad (1996) maupun Agnes (2005), seorang analis harus mempunyai pengertian yang mendalam tentang bentuk-bentuk laporan keuangan, yang terdiri dari;

\section{Neraca}

Neraca adalah laporan keuangan yang melaporkan jumlah kekayaan, kewajiban keuangan, dan modal sendiri perusahaan pada waktu tertentu. Secara garis besar, neraca memberikan informasi mengenai sumber dan penggunaan dana perusahaan. Sisi sebelah kiri neraca (Aktiva) merupakan sisi penggunaan dana perusahaan, yakni berupa kebijakan investasi, baik investasi jangka panjang, maupun investasi jangka pendek yang dilakukan perusahaan selama periode tercentenary

pendekatan kontribusi dan pendekatan fungsional. Pendekatan kontribusi membagi biaya-biaya kedalam dua sifat pokok, yakni biaya variable dan biaya tetap. Pendekatan ini biasanya dipergunakan dalam pengambilan keputusan manajemen berkenaan dengan perencanaan biaya, volume, dan laba. Laporan laba rugi yang disusun dengan pendekatan fungsional memberikan informasi mengenai biaya-biaya yang dikeluarkan oleh setiap fungsi utama dalam perusahaan (fungsi produksi, pemasaran, sumber daya manusia dan umum, serta fungsi keuangan).

Dalam pengukuran laba perusahaan, pendekatan fungsional dapat memberikan informasi yang jelas mengenai, penyimpangan yang dilakukan oleh setiap departemen (fungsi) yang ada dalam perusahaan atas penyimpangan yang terjadi terhadap target laba perusahaan.

\section{Laporan Laba Yang Ditahan}

Laporan laba yang ditahan adalah laporan yang menunjukkan sebab-sebab terjadinya perubahan dalam saldo yang ditahan.

\section{Laporan Sumber dan Penggunaan Dana}

Laporan sumber dan penggunaan dana atau disebut juga sebagai laporan perubahan posisi keuangan laba yang ditahan adalah laporan yang menunjukkan sebab-sebab terjadinya perubahan dalam saldo yang ditahan.

\section{Sifat Laporan Keuangan}

Laporan Keuangan bersifat historis serta menyeluruh dan sebagai suatu progress report. Laporan keuangan terdiri dari data yang merupakan kombinasi dari :

a. Fakta yang telah dicatat (record fact) yang berarti bahwa laporan keuangan dibuat atas dasar fakta dari catatan akuntansi. Pendapatan dari pos-pos ini berdasarkan catatan historis dari peristiwa-peristiwa yang telah terjadi dimasa lampau dan jumlah uang yang tercatat dalam pospos itu dinyatakan dalam harga-harga pada waktu terjadinya peristiwa (an original cost).

b. Prinsip-prinsip dan kebiasaan-kebiasaan di dalam akuntansi, yang berarti bahwa data yang dicatat itu didasarkan pada prosedur maupun anggapananggapan tertentu yang merupakan prinsip-prinsip akuntansi yang berlaku umum (General Accepted Accounting Prinsiples).

c. Pendapat Pribadi (Personal Judgement), yang berarti bahwa walaupun pencatatan transaksi telah diatur oleh konvensi-konvensi atau dalil-dalil dasar 
yang sudah ditetapkan namun penggunaannya tergantung daripada akuntan atau manajemen perusahaan yang bersangkutan. Dengan kata lain tergantung pada kemampuan atau integritas pembuatnya yang dikombinasikan dengan fakta yang tercatat (Munawir 2004).

\section{Keterbatasan Laporan Keuangan}

Laporan Keuangan mempunyai keterbatasan, antara lain:

a. Laporan Keuangan yang dibuat secara periodik pada dasarnya merupakan interim report (laporan yang dibuat antara waktu tertentu yang sifatnya sementara) dan bukan merupakan laporan yang final.

b. Laporan keuangan menunjukkan angka dalam rupiah yang kelihatannya bersifat pasti dan tepat, tapi sebenarnya dasar penyusunannya dengan standar nilai yang mungkin berbeda atau berubah-ubah.

c. Laporan keuangan disusun berdasarkan hasil pencatatan transaksi keuangan atau nilai rupiah dari berbagai waktu dan tanggal yang lalu dimana daya beli uang tersebut semakin menurun, sehingga kenaikan volume penjualan yang dinyatakan dalam rupiah belum tentu menunjukkan unit yang dijual semakin besar.

d. Laporan keuangan tidak dapat mencerminkan beberapa faktor yang mungkin mempengaruhi posisi atau keadaan keuangan perusahaan karena faktor-faktor tersebut tidak dapat dinyatakan dengan satuan uang, misalnya prestasi keuangan, adanya kontrak-kontrak penjualan maupun pembelian yang telah disetujui, kemanapun dan integritas manajer dan sebagainya (Munawir, 2004).

\section{Metode dan Teknik Analisis Laporan Keuangan}

Metode dan teknik analisis yang digunakan dalam analisis laporan keuangan (Sofyan, 2001), (Agnes, 2005), dan (Keown, 2004) adalah sebagai berikut:

\section{Analisis Perbandingan Laporan Keuangan (Komparatif)}

Metode ini digunakan dengan memanfaatkan angka-angka laporan keuangan dan membandingkannya dengan angka-angka laporan keuangan lainnya. Perbandingan merupakan langkah-langkah yang amat penting dalam proses analisis terutama analisis terhadap laporan keuangan. Dengan analisis perbandingan ini akan dibahas dalam dua unsur yaitu neraca dan perhitungan laba rugi. Analisa perbandingan dari laporan keuangan akan memberi suatu gambaran tentang posisi keuangan dari suatu perusahaan.

\section{Analisis Trend (Trend Analysis)}

Analisis ini harus menggunakan teknik perbandingan laporan keuangan beberapa tahun, yang digambarkan adalah kecenderungannya. Analisis Trend ini biasanya dibuat melalui grafik dan untuk itu perlu dibantu oleh pengetahuan statistik misalnya menggunakan linier programming, rumus chi square ataupun model garis lurus seperti $\mathrm{y}=\mathrm{a}+\mathrm{b} \mathrm{x}$.

\section{Laporan Keuangan Bentuk Awam (Common Size Financial Statement)}

Merupakan teknik analisis yang menyajikan laporan keuangan dalam bentuk presentasi. Presentasi itu biasa dikaitkan dengan suatu jumlah yang dinilai 
penting misalnya asset untuk neraca, penjualan untuk laba-rugi.

\section{Metode Index Times Series}

Dalam metode ini dihitung indeks dan digunakan untuk mengkonversikan angka-angka laporan keuangan. Biasanya ditetapkan tahun dasar yang diberi indeks 100. Beranjak dari tahun dasar inilah maka dibuat indeks tahun-tahun lainnya sehingga dapat dibaca dengan mudah perkembangan angka-angka laporan keuangan perusahaan tersebut pada periode lain.

\section{Metode Analisis Rasio Laporan Keuangan}

Rasio laporan keuangan adalah perbandingan antara pos-pos tertentu dengan pos lain yang memiliki hubungan signifikan. Rasio keuangan ini hanya menyederhanakan hubungan antara pos tertentu dengan pos lainnya. Dengan penyederhaan ini maka yang berkepentingan dapat menilai hubungan antara pos tersebut dan dapat membandingkannya dengan rasio lain sehingga dapat memberikan penilaian.

\section{Analisis Sumber dan Penggunaan Kas dan Dana}

Analisis sumber dan penggunaan dana dilakukan dengan menggunakan laporan keuangan dua periode. Dari laporan keuangan tersebut maka akan diketahui sebab-sebab berubahnya modal kerja dalam periode tertentu.

\section{Analisis Break Event}

Dengan Analisis Break Event dapat diketahui :

a. Hubungan antara penjualan, biaya, dan laba.

b. Struktur biaya tetap dan biaya variabel.

c. Kemampuan perusahaan memberikan margin untuk menutupi biaya tetap

d. Kemampuan perusahaan dalam menekan biaya dan batas di mana perusahaan mengalami laba dan juga tidak mengalami rugi.

\section{Analisis Laba Kotor (Gross Profit Analysis)}

Analisis laba kotor lazim digunakan dalam perencanaan keuangan atau budgeting. Namun teknik ini biasa digunakan dalam analisis laporan keuangan. Analisis ini menggunakan data penjualan, biaya variabel (harga pokok produksi) dan laba kotor.

9. Analisis Du Pont

Analisis Du Pont merupakan pendekatan terpadu (integratif) atas analisis rasio keuangan. Metode Analisis Du Pont ini menggabungkan rasio-rasio aktivitas dan profit margin, dan menunjukkan bagaimana rasio-rasio tersebut berinteraksi untuk menentukan profitabilitas aktiva yang dimiliki perusahaan. Proses analisis Du Pont disebut dengan pengendalian terhadap tingkat pengembalian investasi (Return On Investment/ROI). Jika ROI untuk suatu perusahaan berada dibawah angka yang ditargetkan, melalui sistem Du Pont dapat ditelusuri sebab-sebab terjadinya penurunan ROI.

Selanjutnya pada penelitian ini penulis membatasi pembahasan dengan menggunakan metode dan teknik Analisis Rasio Keuangan (Rasio Likuiditas, Rasio Solvabilitas, Rasio Aktifitas, dan Rasio Rentabilitas).

\section{Alat Analisis Rasio Keuangan}

Analisis Rasio Keuangan merupakan salah satu bentuk metode/teknik dari analisis keuangan yang sering digunakan oleh perusahaan. Hasil analisis rasio 
keuangan dapat memberikan informasi mengenai posisi dan kondisi keuangan perusahaan dan dapat membantu proses pengambilan keputusan bagi pihakpihak yang berkepentingan. Kondisi finansial perusahaan dalam keadaan baik atau menuju penurunan dan akan mengalalami kesulitan finansial. Begitu besarnya peranan dan kegunaan dari analisis rasio keuangan terhadap gambaran keuangan dan perusahaan sehingga menuntut ketepatan dan kecermatan dalam menganalisis laporan keuangan.

Berdasarkan teknik analisis rasio keuangan, maka jenis-jenis rasio keuangan (Bambang, 1998), (Agnes, 2005), (Gill, 2005), dan (Keown, 2004) terdiri dari :

\section{Rasio Pengukur Likuiditas}

Yaitu analisis rasio untuk mengukur kemampuan perusahaan untuk memenuhi kewajibannya yang jatuh tempo.

a. Rasio Lancar (Current Ratio), yaitu untuk menghitung berapa kemampuan perusahaan dalam membayar utang lancar dengan aktiva lancar yang tersedia. Apabila rasio rendah menandakan perusahaan tidak mampu melunasi tagihantagihannya secepat mungkin, dan tidak mampu untuk mengambil keuntungan dari potongan kas atau hal-hal lain yang diharapkan. Tingginya persediaan berarti juga tingginya hutang dagang. Apabila rasio tinggi berarti uang yang dipergunakan dalam menjalankan perusahaan ditahan dalam sekuritas (surat berharga) milik pemerintah, tabungan tunai, atau dana-dana lainnya. Rasio yang baik untuk perusahaan tergantung pada jenis perusahaan, waktu didalam siklus usaha, dan umur usaha.

b. Rasio Cepat (Quick Ratio), yaitu untuk menghitung berapa kemampuan perusahaan dalam membayar utang lancar dengan aktiva yang lebih liquid, atau rasio ini menunjukkan kemampuan perusahaan untuk membayar hutang jangka pendeknya tanpa memperhitungkan persediaan. Tidak disertakan persediaan dalam aktiva lancar, karena persediaan memerlukan waktu yang lama untuk direalisasikan menjadi uang tunai.

\section{Rasio Pengukur Solvabilitas}

Yaitu analisis rasio untuk mengukur kemampuan perusahaan untuk membayar semua hutangnya (baik jangka pendek maupun jangka panjang), apabila perusahaan dibubarkan/dilikuidasi.

a. Rasio Hutang (Debt Ratio), yaitu pengukuran jumlah aktiva perusahaan yang dibiayai oleh utang atau modal yang berasal dari kreditur. Rasio ini memperlihatkan proporsi antara kewajiban yang dimiliki dengan seluruh kekayaan yang dimiliki. Semakin tinggi persentasenya cenderung semakin besar risiko keuangannya bagi kreditor maupun pemegang saham.

b. Rasio Hutang Terhadap Modal (Total Debt to Equity Ratio/DER), yaitu menghitung perbandingan antara utang jangka panjang dengan modal sendiri.

\section{Rasio Pengukur Aktivitas}

Yaitu analisis rasio yang bertujuan untuk mengetahui efektivitas pemakaian aktiva yang diinvestasikan dalam kegiatan usaha perusahaan.

a. Rasio Perputaran Jumlah Aktiva (Total Assets Turnover Ratio), yaitu untuk mengukur berapa kali dana yang tertanam dalam persediaan berputar 
dalam setahun, rasio ini juga menunjukkan efektivitas penggunaan seluruh harta perusahaan dalam rangka menghasilkan penjualan atau menggambarkan berapa rupiah penjualan bersih yang dapat dihasilkan oleh setiap rupiah yang diinvestasikan dalam bentuk harta perusahaan.

b. Rasio Perputaran Piutang (Receivable Turnover Ratio), yaitu untuk menghitung berapa kali dana yang tertanam dalam piutang perusahaan berputar dalam setahun, rasio ini juga menunjukkan cepatnya perbandingan hutang dan ekuitas dalam pendanaan perusahaan menunjukkan kemampuan modal sendiri perusahaan tersebut untuk memenuhi kewajibannya.

c. Rasio Penagihan Rata-rata (Average Collection Turnover Ratio), yaitu untuk menghitung berapa lama rata-rata dana yang tertanam dalam piutang perusahaan berputar dalam setahun, rasio ini juga dapat mengukur efisiensi pengelolaan piutang perusahaan, rata-rata jangka waktu lamanya perusahaan harus menunggu pembayaran setelah melakukan penjualan. Untuk rasio yang rendah menandakan perputaran cepat, yang dapat berupa hasil dari kebijakan pengumpulan yang ketat atau pelanggan yang membayar dengan cepat, sedangkan rasio yang tinggi menandakan perputaran lambat, yang mungkin merupakan hasil dari sejumlah tagihan yang belum dibayar, atau dari kebijakan pengumpulan pajak, atau dari piutang yang digunakan untuk aktivitas penjualan.

\section{Rasio Pengukur Rentabilitas (Profitabilitas)}

Yaitu analisis rasio untuk mengukur kemampuan untuk memperoleh laba melalui semua kemampuan dari sumber yang ada seperti kegiatan penjualan, kas, modal, dan sebagainya.

a. Rasio Pengembalian Atas Total Aktiva (Return on Assets Ratio/ROA), yaitu mengukur tingkat penghasilan bersih yang diperoleh dari total aktiva perusahaan, rasio ini juga memberikan ukuran produktivitas aktiva dalam memberikan pengembalian kepada kreditor maupun pemegang saham. Rasio yang rendah menandakan kinerja yang buruk, dimana penggunaan asset yang tidak efisien oleh manajemen. Sedangkan rasio yang tinggi menandakan suatu kinerja keuangan perusahaan yang baik, dimana penggunaan aset yang efisien oleh manajemen. Rasio ini dikenal juga dengan istilah Rasio Pengembalian Investasi (Return on Investment ratio/ROI), yaitu rasio yang menunjukkan berapa besar laba bersih diperoleh perusahaan bila diukur dari nilai aktivanya.

b. Rasio Pengembalian Atas Modal (Return on Equity Ratio/ROE), yaitu mengukur tingkat penghasilan bersih yang diperoleh oleh pemilik perusahaan atas modal yang diinvestasikan, rasio ini juga memperlihatkan sejauh mana perusahaan mengelola modal sendiri secara efektif, mengukur tingkat keuntungan dari investasi yang telah dilakukan pemilik modal sendiri atau pemegang saham perusahaan. ROE menunjukkan rentabilitas modal sendiri atau yang sering disebut sebagai rentabilitas usaha.

c. Rasio Margin Laba Bersih (Net Profit Margin Ratio), yaitu mengukur laba bersih sesudah pajak dibandingkan dengan volume penjulan, rasio ini juga menunjukkan kemampuan setiap rupiah penjualan menghasilkan laba bersih Net Profit Margin disebut juga dengan Earning After Tax (EAT). Untuk rasio 
yang rendah menunjukkan bahwa tingkat keuntungan atas penjualan memiliki margin yang rendah ataupun memiliki perputaran persediaan yang tinggi sedangkan untuk rasio yang tinggi biasanya menunjukkan usaha yang lebih baik.

\section{METODE PENELITIAN \\ Pendekatan Penelitian}

Pendekatan penelitian yang digunakan penulis dalam penelitian ini adalah penelitian deskriptif kuantitatif, yaitu suatu metode penelitian yang bertujuan untuk membuat deskripsi secara sistematis, faktual, dan akurat mengenai faktafakta dan sifat-sifat dari obyek penelitian. Selanjutnya dalam pembahasan ini akan dijelaskan secara sistematis gambaran mengenai kinerja keuangan PT. Indosat, Tbk dan PT. HM. Sampoerna, Tbk berdasarkan data-data yang faktual dan akurat.

\section{Lokasi Penelitian}

Pada penelitian ini penulis menggunakan data laporan keuangan tahun 2016 dari PT. Indosat, Tbk dan PT. HM. Sampoerna, Tbk. Penelitian ini dilakukan di Bursa Efek Indonesia melalui kantor kuasa perwakilannya di Makassar yaitu Pusat Informasi Pasar Modal (PIPM) yang berlokasi di Jl. Dr. Ratulangi Makassar, Sulawesi Selatan.

\section{Variabel dan Pengukurannya}

Variabel pada laporan keuangan yang penulis gunakan dalam pembahasan analisis kinerja keuangan PT. Indosat, Tbk dan PT. HM. Sampoerna, Tbk adalah sebagai berikut:

- Aktiva Lancar (Current Assets)

- Persediaan (Inventory)

- Hutang/Kewajiban Lancar (Current Liabilities)

- Hutang/Kewajiban (Liabilities / Debt)

- Aktiva (Assets)

- Total Modal (Total Equity)

- Penjualan(Sales)

- Aktiva Tetap (Fixed Assets)

- Piutang (Receivable)

- Pendapatan/Laba Bersih (Net Income)

Pengukuran variabel-variabel diatas diukur dengan skala rasio dan persentase.

\section{Teknik Pengumpulan Data}

Sesuai dengan jenis data yang diperlukan yaitu data sekunder, maka metode pengumpulan data dalam penelitian ini adalah dengan menggunakan metode Studi Dokumentasi. Teknik ini bermaksud untuk memperoleh data sekunder yaitu dengan cara mempelajari berbagai dokumen dan data yang telah diolah yang diperoleh langsung dari Perusahaan Manufaktur yang terdaftar di Bursa Efek Indonesia berupa Laporan Keuangan.

\section{Metode Analisis Data}

Pada penelitian ini digunakan metode penelitian deskriptif dengan metode analisis data yang dipakai adalah analisis kuantitatif dan kualitatif. Analisis 
deskriptif kuantitatif adalah analisis data dengan berdasarkan pada angka-angka, persentase, frekuensi, rata-rata, diagram atau grafik dimana untuk mengolahnya dapat digunakan statistik deskriptif. Analisis deskriptif kualitatif adalah analisis yang didasarkan pada pernyataan keadaaan dan ukuran kualitas.

Adapun langkah-langkah yang dilakukan dalam melakukan analisis kinerja keuangan yaitu dengan menggunakan metode atau teknik sebagai berikut:

1. Metode Analisis Rasio Keuangan, yaitu mengukur variabel-variabel laporan keuangan dengan skala rasio dan persentase baik dengan teknik Analisis Rasio Likuiditas, Solvabilitas, Rasio Aktivitas maupun Rasio Rentabilitas (Profitabilitas).

Perhitungan masing-masing rasio dalam Analisis Rasio Keuangan menggunakan rumus sebagai berikut:

a. Rasio Pengukur Likuiditas

Yaitu analisis rasio untuk mengukur kemampuan perusahaan untuk memenuhi kewajibannya yang jatuh tempo.

1) Rasio Lancar (Current Ratio)

$$
\text { CurrentRatio }=\frac{\text { Current Assets }}{\text { Current Liabilities }} \times 100 \%
$$

2) Rasio Cepat (Quick Ratio)

$$
\text { Quick Ratio }=\frac{\text { Asset }- \text { Inventoryx }}{\text { Lialibilities }} 100 \%
$$

\section{Lialibilities}

\section{b. Rasio Pengukur Solvabilitas}

Yaitu analisis rasio untuk mengukur kemampuan perusahaan untuk membayar semua hutangnya (baik jangka pendek maupun jangka panjang), apabila perusahaan dibubarkan/dilikuidasi.

1) Rasio Hutang (Debt Ratio)

$$
\text { DebtRatio }=\frac{\text { Total Debt }}{\text { Total Assets }} \times 100 \%
$$

2) Rasio Hutang Terhadap Modal

$$
\text { Total Debt to Equity Ratio }=\frac{\text { Total Debtx }}{\text { Total Equity }} 100 \%
$$

c. Rasio Pengukur Aktivitas

Yaitu analisis rasio yang bertujuan untuk mengetahui efektivitas pemakaian aktiva yang diinvestasikan dalam kegiatan usaha perusahaan.

1) Rasio Perputaran Jumlah Aktiva

$$
\text { Total Asset }=\frac{\text { SalesTurnoverRatio }}{\text { TotalAssets }} \times 100 \%
$$

2) Rasio Perputaran Piutang (Receivable Turnover Ratio)

$$
\text { ReceivableTurnover Ratio }=\frac{\text { Sales }}{\text { Receivable }} \times 100 \%
$$

d. Rasio Pengukur Rentabilitas (Profitabilitas)

Yaitu analisis rasio untuk mengukur kemampuan untuk memperoleh laba.

1) Rasio Pengembalian Atas Total Aktiva (Return on Assets Ratio/ROA) 


$$
\text { Return on Assets Ratio }=\frac{\text { Net Income }}{\text { Total Assets }}
$$

2) Rasio Pengembalian Atas Modal (Return on Equity Ratio/ROE)

$$
\text { Return on Equity }=\frac{\text { Net Income }}{\text { Net Worth }}
$$

3) Rasio Margin Laba Bersih (Net Profit Margin Ratio)

Net Profit Margin Ratio = Earning After Tax

$$
\text { Sales }
$$

\section{ANALISIS DAN PEMBAHASAN}

Sebagai langkah awal untuk melakukan analisis dan pembahasan, maka disajikan laporan keuangan PT. Indosat Tbk dan PT. HM. Sampoerna Tbk (lihat lampiran), dalam bentuk neraca dan laporan laba rugi tahun 2016. Laporan keuangan tersebut dianalisis dengan menggunakan analisis rasio keuangan yang terdiri dari rasio likuiditas, rasio solvabilitas, rasio aktivitas dan rasio rentabilitas.

Suatu analisis rasio secara umum merupakan langkah awal dalam analisis keuangan. Rasio-rasio tersebut dirancang untuk menghasilkan angka yang akan membandingkan dengan dari satu pos laporan keuangan dengan pos lainnya yang mempunyai hubungan yang relevan dan berarti.

\section{Analisis Rasio Likuiditas}

Adapun hasil perhitungan untuk Analisis Rasio Likuiditas adalah sebagai berikut:

\section{Tabel 1}

Rasio Likuiditas PT. Indosat Tbk dan PT. HM. Sampoerna Tbk

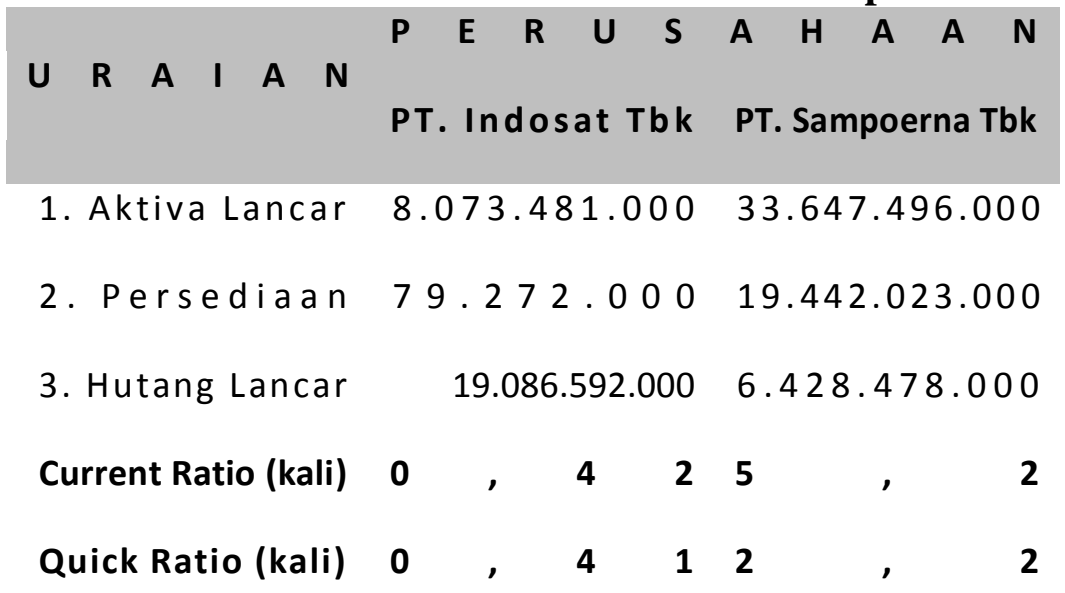

Berdasarkan tabel diatas, rasio lancarPT. Indosat, Tbk adalah sebesar 0,42 kali artinya setiap hutang lancar Rp. 1,- dijamin oleh aktiva lancar sebesar Rp. 0,42 serta rasio lancar PT HM. Sampoerna, Tbk adalah sebesar 5,2 kali artinya setiap hutang lancar Rp. 1,- dijamin oleh aktiva lancar sebesar Rp. 5,2.

Untuk rasio cepatPT. Indosat, Tbk adalah sebesar 0,41 kali artinya setiap hutang lancar Rp. 1,- dijamin oleh aktiva lancar sebesar Rp. 0,41 serta rasio lancar PT HM. Sampoerna, Tbk adalah sebesar 2,2 kali artinya setiap hutang lancar Rp. 1,- dijamin oleh aktiva lancar sebesar Rp. 2,2. 
Jadi, dalam hal rasio lancar dan rasio cepat PT. HM. Sampoerna Tbk lebih likuid dibandingkan dengan PT. Indosat Tbk. Hal ini dapat diartikan bahwa kinerja keuangan PT. HM. Sampoerna Tbk dikatakan baik, karena rasio lancarnyaasih lebih tinggi dari PT. Indosat T

\section{Analisis Rasio Solvabilitas}

Adapun hasil perhitungan untuk Analisis Rasio Solvabilitas adalah sebagai berikut :

Tabel2

Rasio Solvabilitas PT. Indosat Tbk dan PT. HM. Sampoerna Tbk

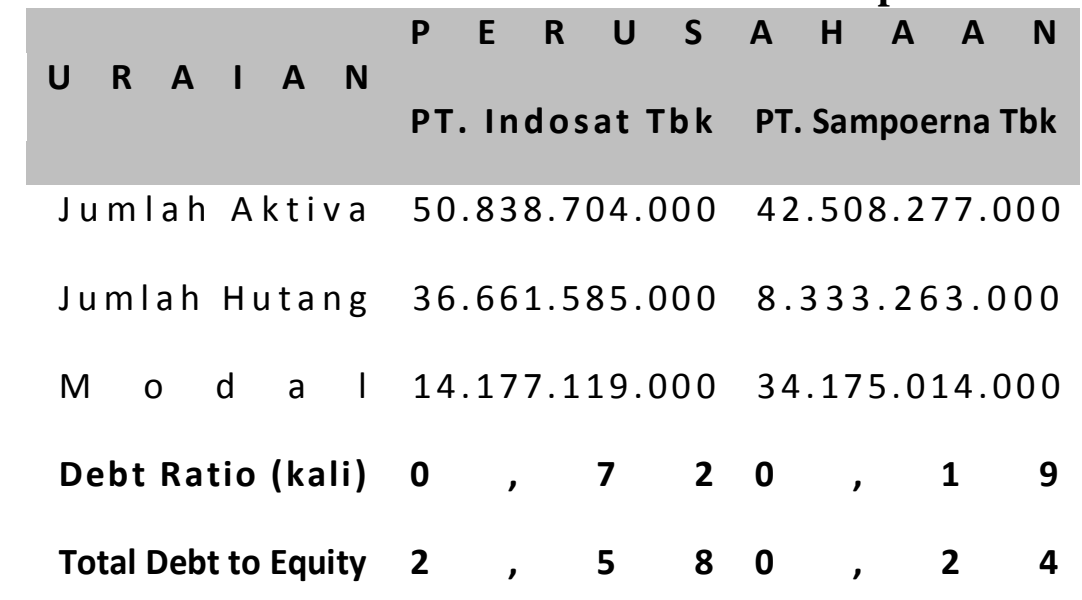

Berdasarkan tabel diatas, rasio hutangPT. Indosat, Tbk adalah sebesar 0,72 kali artinya Rp. 0,72,- hutang dijamin oleh keseluruhan kekayaan perusahaan sebesar Rp. 1 dan rasio hutang PT. HM. Sampoerna, Tbk, adalah sebesar 0,19 kali artinya Rp. 0,019,- hutang dijamin oleh keseluruhan kekayaan perusahaan sebesar Rp. 1,

Untuk rasio hutang terhadap modal PT Indosat, Tbk adalah sebesar 2,58 kali artinya setiap Rp. 2,58,-- dari setiap modal/ekuitas menjadi jaminan hutang dan rasio hutang terhadap modal PT HM. Sampoerna, Tbk adalah sebesar 0,24 kali artinya setiap Rp. 0,24,-- dari setiap modal/ekuitas menjadi jaminan hutang.

Jadi, dalam hal rasio hutang dan rasio hutang terhadap modal, PT. Indosat Tbk hutangnya lebih dapat dijamin oleh perusahaan tersebut dibandingkan dengan PT. PT. HM. Sampoerna Tbk. Hal ini dapat diartikan bahwa kinerja keuangan PT. Indosat Tbk dikatakan baik, karena rasio hutang dan rasio hutang terhadap modal lebih besar dari PT. HM. Sampoerna, Tbk.

3. Analisis Rasio Aktivitas

Adapun hasil perhitungan untuk Analisis Rasio Aktivitas adalah sebagai berikut:

\section{Tabel 3}

Rasio Aktivitas PT. Indosat Tbk dan PT. HM. Sampoerna Tbk

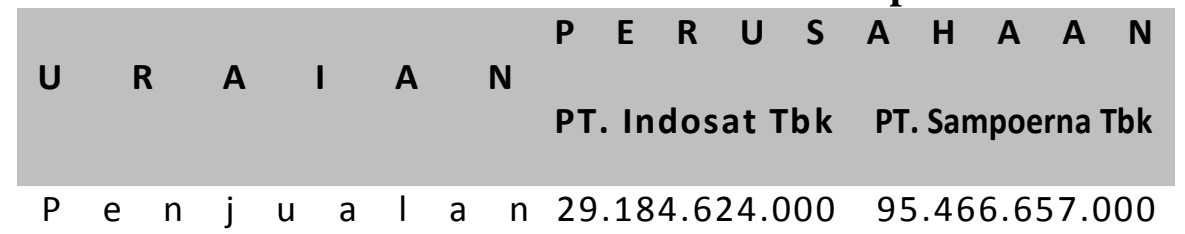




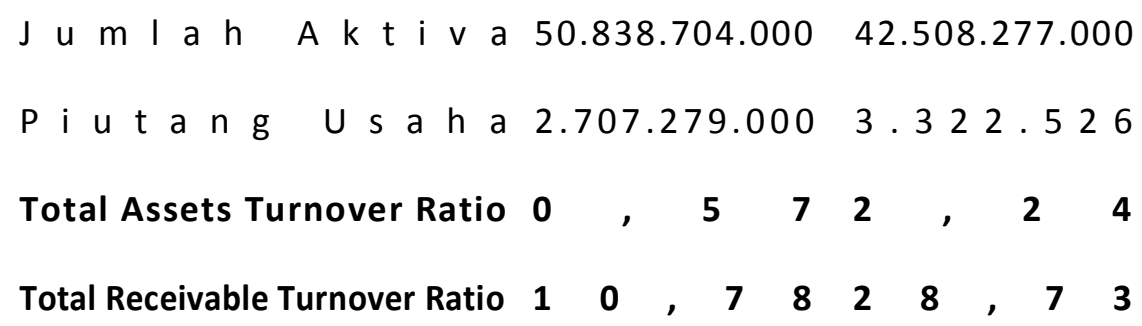

Berdasarkan tabel diatas, rasio perputaran jumlah aktiva PT Indosat, Tbk adalah 0,57 kali artinya dana yang tertanam dalam keseluruhan aktiva rata-rata dalam satu perputarannya adalah 0,57 kali atau setiap rupiah aktiva dalam satu tahun dapat menghasilkan revenue sebesar Rp. 0,57 sedangkan rasio perputaran jumlah aktiva PT HM. Sampoerna, Tbk adalah 2,24 kali artinya dana yang tertanam dalam keseluruhan aktiva rata-rata dalam satu perputarannya adalah 2,24 kali atau setiap rupiah aktiva dalam satu tahun dapat menghasilkan revenue sebesar Rp. 2,24.

Untuk rasio perputaran piutang PT. Indosat, Tbk adalah 10,78 kali artinya dalam satu tahun rata-rata dana yang tertanam dalam piutang berputar $10,78 \mathrm{kali}$ sedangkan rasio perputaran piutang PT. HM. Sampoerna, Tbk adalah 28,73 kali artinya dalam satu tahun rata-rata dana yang tertanam dalam piutang berputar 28,73 kali.

Jadi, dalam hal rasio perputaran jumlah aktiva, dan PT. HM. Sampoernadimana setiap rupiah aktiva dalam satu tahun dapat menghasilkan revenue yang tinggi dibandingkan dengan PT. Indosat Tbk dan rasio perputaran piutang, PT. HM. Sampoerna, Tbk lebih unggul dimana dana yang tertanam dalam piutang berputar 28,73 kali. Hal ini dapat diartikan bahwa kinerja keuangan PT. HM. Sampoerna, Tbk dikatakan baik dibandingkan dengan PT. Indosat, Tbk.

\section{Analisis Rasio Profitabilitas}

Adapun hasil perhitungan untuk Analisis Rasio Profitabilitas adalah sebagai berikut:

\section{Tabel 4}

Rasio Profitabilitas PT. Indosat Tbk dan PT. HM. Sampoerna Tbk

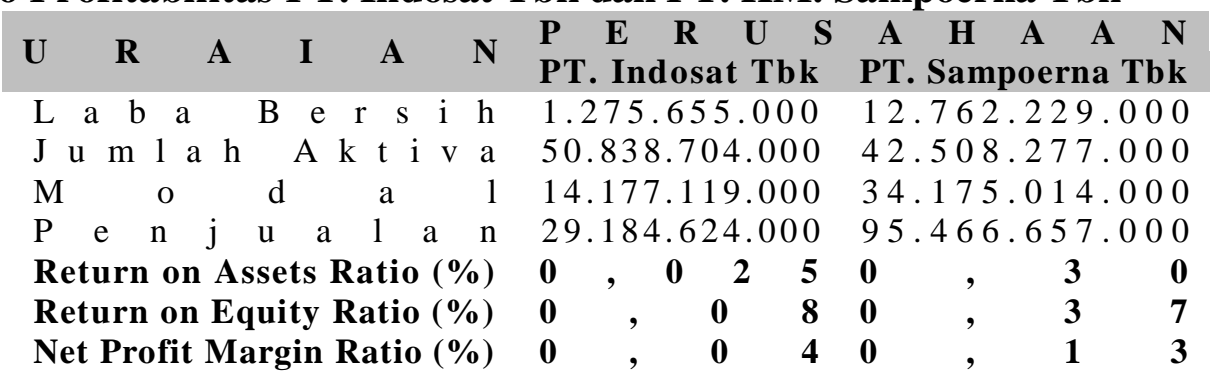

Berdasarkan tabel diatas, rasio hasil pengembalian atas aktiva PT. Indosat, Tbk adalah $0,25 \%$ artinya setiap Rp. 1,- modal menghasilkan laba sebesar Rp. 0,025,- untuk semua investor sedangkan rasio hasil pengembalian 
atas aktiva PT. HM. Sampoerna, Tbk adalah 3,0 \% artinya setiap Rp. 1,modal menghasilkan laba sebesar Rp. 0,30,- untuk semua investor.

Untuk rasio hasil pengembalian atas modal PT. Indosat, Tbk adalah 0,8 $\%$ artinya setiap rupiah modal perusahaan menghasilkan laba bersih sebesar Rp. 0,08 sedangkan rasio hasil pengembalian atas modal PT. HM. Sampoerna, Tbk adalah 3,7 \% artinya setiap rupiah modal perusahaan menghasilkan laba bersih sebesar Rp. 0,37.

Pada rasio margin laba bersih PT. Indosat, Tbk adalah sebesar 0,4 \% artinya setiap rupiah penjualan menghasilkan laba bersih sebesar Rp. 0,04 sedangkan rasio margin laba bersih PT. HM. Sampoerna, Tbk adalah sebesar 1,3 $\%$ artinya setiap rupiah penjualan menghasilkan laba bersih sebesar Rp. 0,13.

Jadi, dalam hal rasio profitabilitas, kinerja keuangan PT. HM. Sampoerna, Tbk lebih baik dibandingkan dengan PT. Indosat, Tbk dan dari segi penerimaan laba bersih yang dihasilkan perusahaan pertahun maka PT. HM. Sampoerna, Tbk kinerjanya lebih baik dibandingkan dengan PT. Indosat, Tbk. Hal ini dapat diartikan bahwa kinerja keuangan PT. HM. Sampoerna, Tbk masih lebih baik karena salah satu keberhasilan perusahaan adalah dilihat dari seberapa besar laba bersih yang dapat dihasilkan oleh perusahaan dalam membiayai segala aktivitas yang terjadi diperusahaan.

\section{KESIMPULAN DAN SARAN \\ Kesimpulan}

Dari hasil pembahasan Analisis Kinerja Keuangan PT Indosat, Tbk dan PT. HM. Sampoerna, Tbk, maka dapat diambil beberapa kesimpulan sebagai berikut:

a. Berdasarkan Rasio Likuiditas, Pencapaian Rasio Likuiditas PT Indosat, Tbk dari tahun 2016 mengalami penurunan dibandingkan standar Rasio Likuiditas Rata-rata Industri Sejenis. Salah satu indikator penyebabnya adalah adanya kenaikan pada hutang lancar.

b. Berdasarkan Rasio Solvabilitas, Pencapaian Rasio Solvabilitas PT. HM. Sampoerna, Tbk dari tahun 2016 menunjukkan hasil yang baik, dimana untuk pencapaian Rasio Hutang (Debt Ratio) berada dibawah standar Rasio Hutang Rata-rata Industri Sejenis, sedangkan untuk pencapaian Rasio Hutang Terhadap Modal (Debt to Equity Ratio) masih dibawah dari maksimal Rasio Hutang Terhadap Modal Rata-rata Industri Sejenis.

c. Berdasarkan Rasio Aktivitas, adanya indikasi bahwa kinerja keuangan PT Indosat, Tbk masih belum baik dilihat dari pencapaian Rasio Aktivitas karena masih di bawah standar Rasio Rata-rata Industri Sejenis. Hal ini menandakan bahwa efektivitas penggunaan aktiva perusahaan masih belum maksimal.

d. Berdasarkan Rasio Profitabilitas, dari hasil pencapaian Rasio Profitabilitas PT. HM. Sampoerna, Tbk. menunjukkan hasil kinerja yang baik dimana pencapaian hasil kinerja tersebut khususnya indikasi dari Net Profit Margin berada diatas dari standar pencapaian Rasio rata-rata Industri Sejenis.

e. Selama periode Tahun 2016, PT. Indosat, Tbk dan PT. HM. Sampoerna, Tbk ada peningkatan biaya yang disebabkan pihak manajemen kurang dapat melakukan efisiensi biaya yang terlihat dari adanya kenaikan beban usaha 
atau pun beban operasional dan non operasional perusahaan (suku bunga, BBM, dan lain-lain).

f. Secara keseluruhan kinerja manajemen PT. Indosat, Tbk dan PT. HM. Sampoerna, Tbk dalam mengelola assets dan memberikan keuntungan bagi para pemegang saham selama periode tahun 2016 mengalami kenaikan, sehingga perusahaan mampu menghasilkan laba dan senantiasa terus berusaha untuk meningkatkan kapasitas produksi dan pelayanan untuk meningkatkan penjualan dan mengoptimalkan laba.

\section{Saran}

Adapun saran-saran yang dapat penulis sampaikan berdasarkan kesimpulan diatas, adalah sebagai berikut:

1. Setiap perusahaan diharapkan agar meningkatkan kemampuan perusahaan dalam mengelola aktiva perusahaan yang pada akhirnya akan dapat meningkatkan laba perusahaan, antara lain dengan melakukan hal-hal sebagai berikut:

a. Meningkatkan penjualan diantaranya dengan menawarkan beragam program marketing yang inovatif dan value yang menarik dan memperluas jaringan dan distribusi mengingat pangsa pasar di sektor telekomunikasi dan perdagangan rokok merupakan pasar yang sangat potensial.

b. Mengoptimalkan penggunaan aktiva tetap, terutama mesin-mesin baru yang menggunakan teknologi modern dan canggih, sehubungan dengan perluasan jaringan dan peningkatan produksi.

c. Melakukan efisiensi biaya-biaya dan meningkatkan pendapatan lainnya diluar penjualan agar dapat menekan harga pokok penjualan, sehingga dapat meningkatkan laba bersih perusahaan.

2. Meningkatkan efisiensi kinerja keuangan perusahaan dalam memanfaatkan modal yang telah ditanamkan untuk memberikan keuntungan bagi pemegang saham, dan juga dengan mengoptimalkan penggunaan hutang diantaranya dengan cara menerbitkan obligasi.

3. Setiap perusahaan sebaiknya terus meningkatkan pertumbuhan market share dan revenue share untuk mengimbangi penurunan ARPU (Average Revenue Per User), memperkuat posisi dominannya di beberapa lokasi secara mendalam dan mempercepat penetrasi pasar untuk daerah-daerah yang Indosat masih belum menjadi market leader.

4. Dalam hal keuangan, khususnya PT Indosat, Tbk. perlu memfokuskan diri dalam pembelanjaan modal serta pemakaian biaya secara lebih efisien untuk dapat mempertahankan pendapatan dan arus kas yang sehat. Hal ini sangat penting mengingat ketidakpastian ekonomi makro dan global yang menyebabkan kondisi permintaan/demand akan jasa telekomunikasi dapat terpengaruh. Sedangkan pendanaan bagi perusahaan dapat mengalami kesulitan akibat efek domino ketidakpercayaan global atas pasar keuangan.

\section{DAFTAR PUSTAKA}

Agnes Sawir. 2005. Analisis Kinerja Keuangan dan Perencanaan Keuangan Perusahaan, PT Gramedia Pustaka Utama, Jakarta. 
Bambang Riyanto. 1998. Dasar-dasar Pembelanjaan Perusahaan, Edisi Keempat, Cetakan Kelima, BPFE Yogyakarta, Yogyakarta.

Gill and Chatton. 2005. Understanding Financial Statement, alih bahasa Dwi Prabaningtyas, Cetakan Ketiga, PPM, Jakarta.

G. Sugiyarso dan F. Winarni.2005. Manajemen Keuangan Pemahaman Laporan Keuangan, Pengelolaan Aktiva, Kewajiban dan Modal, serta Pengukuran Kinerja Perusahaan, Cetakan Pertama, Media Pressindo, Yogyakarta.

Ikatan Akuntan Indonesia. 2015. Pernyataan Standar Akuntansi Keuangan, Salemba Empat, Jakarta.

Keown, J. A., J. D. Martin., J.W. Petty. And D.F. Scott, JR. 2002. Financial Management : Principles and Applications, Ninth Edition, alih bahasa Haryandini, Edisi 9, 2004, PT Index kelompok Gramedia, Jakarta.

Myer, John N. 2002. Financial Statement Analysis, alih bahasa R. Sasmita Adikoesoema, Edisi Ketiga, Aksara Baru, Jakarta.

S. Munawir. 2004. Analisa Laporan Keuangan, Edisi 4, Liberty, Yogyakarta.

Sofyan Syafri Harahap. 2001. Analisis Kritis atas Laporan Keuangan, Raja Grafindo Persada, Jakarta.

Suad Husnan. 1998. Manajemen Keuangan (Teori dan Aplikasi), BPFE Yogyakarta, Yogyakarta. 